\title{
The COVID-19 in the Primary Health Care context
}

\author{
A COVIID-19 no contexto da Atenção Primária à Saúde \\ COVID-19 en el contexto de la Atención Primaria de Salud
}

Received: 03/06/2021 | Reviewed: 03/12/2021 | Accept: 03/16/2021 | Published: 03/23/2021

\author{
Ana Valesca Fernandes Gilson Silva \\ ORCID: https://orcid.org/0000-0002-1877-4843 \\ Municipal Public Health, Brazil \\ Sérgio Arouca Public Health School, Brazil \\ E-mail: amavalescafernandes@hotmail.comr \\ Simone de Pinho Barbosa \\ ORCID: https://orcid.org/0000-0003-1073-3219 \\ Federal University of Juiz de Fora, Brazil \\ E-mail: simone.pinho@ufjf.edu.br \\ Fernanda Moura Lanza \\ ORCID: https://orcid.org/0000-0001-8250-180X \\ Federal University of São João Del Rei, Brazil \\ E-mail: fernandalanza@ufsj.edu.br \\ Maria Marta Amancio Amorim \\ ORCID: https://orcid.org/0000-0001-8268-2508 \\ Centre for Migration Studies and Intercultural Relations, Portugal \\ E-mail: martamorim@hotmail.com \\ Érika de Azevedo Leitão Mássimo \\ ORCID: https://orcid.org/0000-0002-2608-2302 \\ Pontifical Catholic University of Minas Gerais, Brazil \\ E-mail: erikaazevedomassimo@gmail.com
}

\begin{abstract}
This article aims to develop a reflective theoretical study with an emphasis on the actions, challenges and recommendations of practices for the prevention, control and monitoring of PHC disease. The COVID-19 pandemic has been demanding a remodeling of structures, not only in hospital care, but, especially in interventions in communities and their social, urban and structural problems. The article highlights the work process and new technical and dynamic incorporations for prevention, surveillance and monitoring imposed by SARS-CoV2 on primary health care, which must also guarantee access to essential care. As it allows thinking about the most feasible forms of action, this article recognizes the principles of action in the health system, offering to managers and health professionals, through the interlocution between related studies, several measures that can help in assistance of pandemic. The COVID-19 pandemic changed the course of some health policies in the world. Patient-centered care requires a change in perspective towards a concept of community-centered care. As the primary health care is the first level of contact for individuals, family and community in a health system, constituting the preferred gateway to the care process, it is expected that the reflections raised by this article will contribute to an analysis that answers the main public health issues from the perspective of primary health care, preserving its stability, avoiding the disintegration of its actions and maintaining its functionality with the strengthening of local and community actions.
\end{abstract}

Keywords: COVID-19; Coronavirus infections; Pandemics; Health policy; Primary health care.

\section{Resumo}

Esse artigo tem por objetivo desenvolver um estudo teórico reflexivo com ênfase nas ações, nos desafios e recomendações de práticas de prevenção, controle e monitoramento da doença APS. A pandemia do COVID-19 vem exigindo uma remodelação de estruturas, não apenas no atendimento hospitalar, mas principalmente nas intervenções nas comunidades e em seus problemas sociais, urbanos e estruturais. O artigo destaca o processo de trabalho e as novas incorporações técnicas e dinâmicas de prevenção, vigilância e monitoramento impostas pelo SARS-CoV2 na atenção primária à saúde, o que também deve garantir o acesso a cuidados essenciais. Por permitir pensar nas formas de atuação mais exequiveis, este artigo mapeia princípios de ação no sistema de saúde, oferecendo aos gestores e profissionais, através da interlocução entre os estudos relacionados, diversas medidas que podem auxiliar na assistência em tempos de pandemia. A pandemia do COVID-19 mudou o curso de algumas políticas de saúde no Brasil e no mundo. $\mathrm{O}$ atendimento centrado no paciente requer uma mudança de perspectiva em relação a um conceito de atendimento centrado na comunidade. Como a atenção primária à saúde é o primeiro nível de contato de indivíduos, família e comunidade em um sistema de saúde, constituindo a porta de entrada preferencial para o processo de assistência, espera-se que as reflexões suscitadas por esse artigo contribuam para uma análise que responda às principais questões de saúde pública na perspectiva da atenção primária, preservando sua estabilidade, 
evitando a desintegração de suas ações e mantendo sua funcionalidade com fortalecimento de ações locais e comunitárias.

Palavras-chave: COVID-19; Infecções por coronavírus; Pandemia; Política de saúde; Atenção primária à saúde.

\section{Resumen}

Este artículo tiene como objetivo desarrollar un estudio teórico reflexivo con énfasis en las acciones, desafíos y recomendaciones de prácticas para la prevención, control y seguimiento de la enfermedad de la APS. La pandemia COVID-19 viene exigiendo una remodelación de estructuras, no solo en la atención hospitalaria, sino, especialmente, en las intervenciones en las comunidades y sus problemas sociales, urbanos y estructurales. El artículo destaca el proceso de trabajo y las nuevas incorporaciones técnicas y dinámicas de prevención, vigilancia y seguimiento que impone el SARS-CoV2 a la atención primaria de salud, que también debe garantizar el acceso a los cuidados esenciales. Como permite pensar en las formas de acción más factibles, este artículo reconoce los principios de acción en el sistema de salud, ofreciendo a los gestores y profesionales de la salud, a través de la interlocución entre estudios relacionados, varias medidas que pueden ayudar en la asistencia de una pandemia. La pandemia de COVID-19 cambió el rumbo de algunas políticas de salud en el mundo. La atención centrada en el paciente requiere un cambio de perspectiva hacia un concepto de atención centrada en la comunidad. Dado que la atención primaria de salud es el primero nivel de contacto de los individuos, la familia y la comunidad en un sistema de salud, constituyendo la puerta de entrada preferente al proceso de atención, se espera que las reflexiones suscitadas por este artículo contribuyan a un análisis que dé respuesta a las principales Los temas de salud pública desde la perspectiva de la atención primaria de salud, preservando su estabilidad, evitando la desintegración de sus acciones y manteniendo su funcionalidad con el fortalecimiento de las acciones locales y comunitarias.

Palabras clave: COVID-19; Infecciones por coronavirus; Pandemia; Política de Salud; Atención Primaria de Salud.

\section{Introduction}

In March 2020, the World Health Organization (WHO) declared the disease named as COVID-19, caused by the new corona virus SARS-COV-2 as a pandemic. COVID-19 is a respiratory infection which was first detected in Wuhan, China, a region of origin different from previous pandemics viruses (Lipsitch, Swerdlow \& Finelli, 2020). The rapid spread of the disease showed the vulnerability of health care to combat the pandemic, from health policies to the organization of services (Freitas, Napimoga \& Donalisio, 2020). World leaders make an effort to contain the spread of the virus through a variety of actions that include regional blockages, travel restrictions and social distance and isolation in order to reduce fatalities and try to maintain the capacity of health services. However, there is an urgent necessity to expand public health activities and contain measures. The unprecedented increase in healthcare demand and the lack of hospital supplies, technological equipment and well-trained professionals has impacted the structure of healthcare assistance and, consequently, its process and results.

The experience of China in combating the disease showed the importance of timely information to guide an effective public health response (Kvalsvig et al., 2020). The report on China's COVID-19 experience recommends a disease response planning based on evaluation of local risks to establish differentiated strategies for areas (i) without cases, (ii) with sporadic cases, (iii) with groups of cases and (iv) transmission at the community level. This report also shows that priority should be given to early investigations, including transmission within families (WHO, 2020a). This experience confirms that the effectiveness of a health policies depends on the presence of an accessible, comprehensive and integral Primary Health Care (PHC), which includes actions to promote health, prevent diseases and injuries and rehabilitation (WHO, 2018).

Due to this pandemic, patient-centered care requires a change in perspective towards a concept of communitycentered care (Harzheim et al., 2020). Hospitals are quickly populated by infected patients, facilitating the transmission to uninfected patients. The transportation of infected patients also contributes to spreading the disease, as ambulances and health professionals quickly become vectors, as they are often asymptomatic carriers. Thus, pandemic solutions are needed for the entire population, not just hospitals (Nacoti et al., 2020).

In this way, COVID-19 has been demanding a remodeling of structures and work processes of health services, especially in primary health care, to ensure that its professionals have a technical, scientific, dignified and humanitarian performance (Barbosa \& Silva, 2020). 
Considering the emergency in public health and the importance of knowledge in time to contextual events, this study discusses the pandemic of COVID-19 and its health policies in the context of PHC. This pandemic has been challenging in guaranteeing care and resources at different levels of healthcare, however the role of PHC has been little discussed.

\section{Methodology}

This is a descriptive and exploratory study, with theoretical reflection on the pandemic of COVID19 in the context of Primary Health Care. To support the object of the study, in addition to scientific articles published in national and international journals available online, official publications from national and international bodies and institutions were used. Data collection was based on the Virtual Health Library, using the following descriptors: COVID-19, Primary Health Care, surveillance, management.

A thematic analysis of the publications was carried out, which were categorized by themes: 1 . Context; 2 . Epidemiology; 3. Response management: risk communication, clinical case and contact management, infection prevention and control; 4. Recommendations.

Then, after the organization and logical ordering of the categories (Pereira et al, 2018), the reflective theoretical text on COVID-19 in a specific field, the Primary Health Care, was elaborated. The impacts of the pandemic were analysed, and the multiplicity and the complexity of the actions required to face it and the future challenges related to the disease on the Primary Healthy Care were described.

\section{Performance of Primary Care in COVID-19 Pandemic}

The profile of COVID-19 suggests that $80 \%$ of cases are mild, about $15 \%$ of people react severely and another $5 \%$ require intensive care (Kvalsvig et al., 2020). The severity and healthcare pyramid (Figure 1) shows the integration and variation of approaches to health system assistance in pandemic control (Kvalsvig et al., 2020). In this scheme, it is possible to note the proximity of the community to the PHC, which is the gateway to the health system, which takes care of mild and convalescent cases.

Hospital and intensive care units identify and treat severe acute respiratory infections (SARI), which require advanced technological resources. Severe cases disproportionately affect the elderly and people with underlying medical conditions, such as cardiovascular disease, hypertension and diabetes, which are one of the priority groups for monitoring PHC (WHO, 2020 b). In the basis of pyramid there is the PHC, closer to the community, that can perform the clinical management of mild cases of COVID-19 through a continuous care process (Harzheim et al., 2020; WHO, 2020b; Starfield, 2002).

In this way, the PHC is the first level of contact for individuals, family and community in a health system, constituting the preferred gateway to the care process. The PHC has essential attributes such as longitudinally, management of care, integrality, cultural competence and community and family orientation. Therefore, PHC can reach individuals and families through their full participation and with a positive cost-benefit for the community and the country (Starfield, 2002). 
Figure 1. Severity and healthcare pyramid of COVID-19.

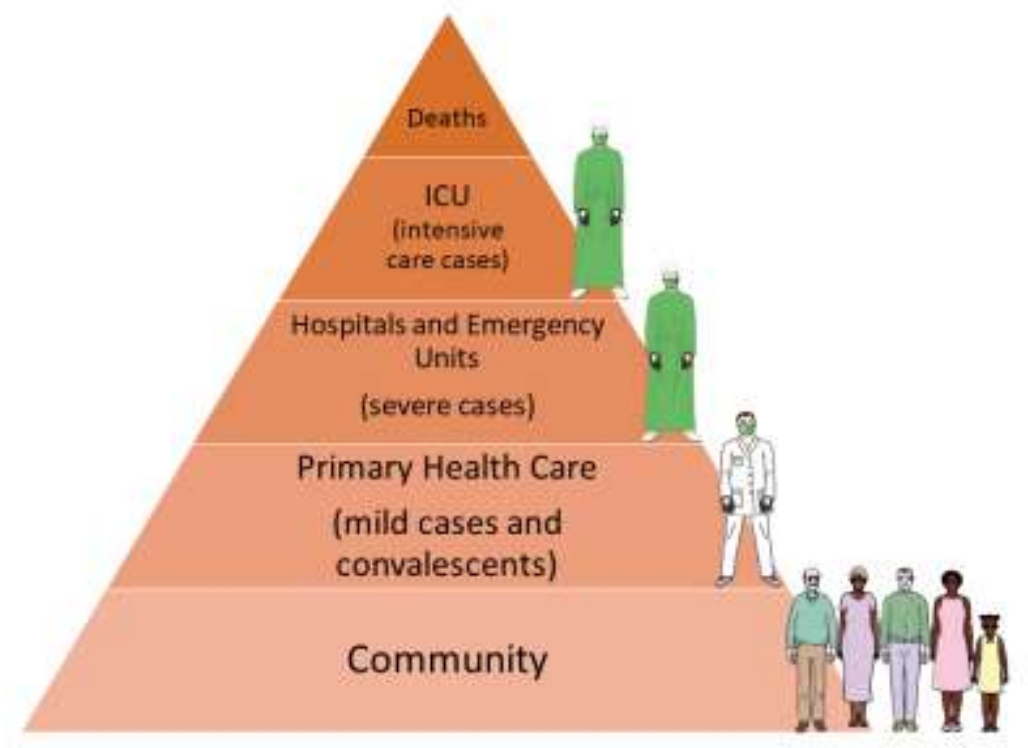

Source: Authors (2021).

Many countries have quite different ways of organization and operating PHC. Some of them offer a selective model of PHS with few services for the poorest populations (Cueto, 2004). In others, like Singapore, considered one of the best public health systems in the world, and Brazil, an emerging country, PHC is the first level of the health care system responsible for an expanded offer of health promotion, disease prevention, diagnosis and treatment services. Also, in these countries, PHC assists in the coordination of services of different complexities (Tan \& Earn, 2019; Castro et al., 2019). The professional teams are composed of nurses, doctors, nursing technicians, community health agents, among others (Harzheim et al., 2020). The PHC competence is sustained based on (i) accessibility, due to the location of the health care unit, (ii) the set of actions, services and procedures available to the elective population under its responsibility and (iii) the continuity of health care in an uninterrupted sequence of events (Starfield, 2002). Therefore, PHC assists families and community within areas with difficult access, extending and expanding actions throughout the territory.

Due to its location and for being the only health service available in many regions, PHC's professionals can identify behaviors of the population that are not captured by the administrative processes of the surveillance services. This makes it possible to observe and analyze how PHC is working, by identifying whether there is cohesion and adherence to the control measures imposed (Haines et al., 2020; Castro et al., 2020). Thus, the PHC can expand risk communication efforts, guiding patients on the recognition of symptoms and the identification of warning signs, and on the importance of self-care, and the care of family members and people from social life (WHO, 2020b). Also, this proximity results in the creation of bonds, affection and trust between families and professionals (Brasil, 2017). In this way, healthcare professionals become references, facilitating the dissemination of guidelines and encouraging the engagement of communities in prevention and control of the disease individually and in the community.

Moreover, PHC has the capacity to map the contacts of infected people, favoring the monitoring and identification of the spread of infection, which contributes to the description of the general infection rate in the community. Thus, PHC is essential for the surveillance and notification actions of these cases, allowing a quick assessment of the severity of the epidemic in a well-defined population. These data allow local health authorities to extrapolate this rate to a larger population, assisting in the decisions of control measures (Lipsitch, Swerdlow \& Finelli, 2020). 
Furthermore, PHC develops actions to prevent and control infectious diseases to reduce the risk of transmission in the PHC itself, at home and in the community through internationally determined measures that consider the mode that disease is transmitted (Padoveze \& Figueiredo, 2014). In health services, prevention and control of infection occur in two levels of the precautionary system: standard and specific. Standard precautions include the use of personal protective equipment (PPE), methods for cleaning and disinfecting instruments and surfaces, the right management of health-care waste, and hand hygiene actions, the last being considered the most efficient measure for preventing infections, as gloves do not replace the need for appropriate hand hygiene (Padoveze \& Figueiredo, 2014; Greenhalgh et al., 2020). On the other way, specific precautions are taken when the use of standard precautions is not enough to interrupt transmission. They are classified in three categories, based on transmission: contact, droplets and airborne. They include medical gowns, surgical or N95 masks, gloves and eye protector. The PPE used with the proper donning and doffing technique is effective and necessary to protect healthcare professionals (Greenhalgh et al., 2020).

The lack of published clinical trials on interventions for COVID-19 infection in primary health care units negatively affects the PHC's professionals. It is necessary to evaluate the risk of contagion since the current guidance is partially based on indirect evidence, mainly through studies of influenza, Severe Acute Respiratory Syndrome (SARS) and Middle East Respiratory Syndrome (MERS). The recommendation is the combination of different types of equipment for this situation (Greenhalgh et al., 2020).

Health policies on management of COVID-19 require a wide and integrated response from the health care system in short, medium and long term. In the short term, PHC can perform primary care more appropriately during the epidemic by reducing the search for unnecessary emergency and hospital care, handling mild cases and providing timely access to services according to health needs (9). In addition, hospitalized patients who recover and are discharged do not leave the health system, but return to PHC (Figure 2). Note the continuous flow of cases of patients with mild illness that can evolves to severe and be referred to the hospital. These patients, when recovered, the convalescents, return to PHC.

Figure 2. Flow of care between hospital and PHC.

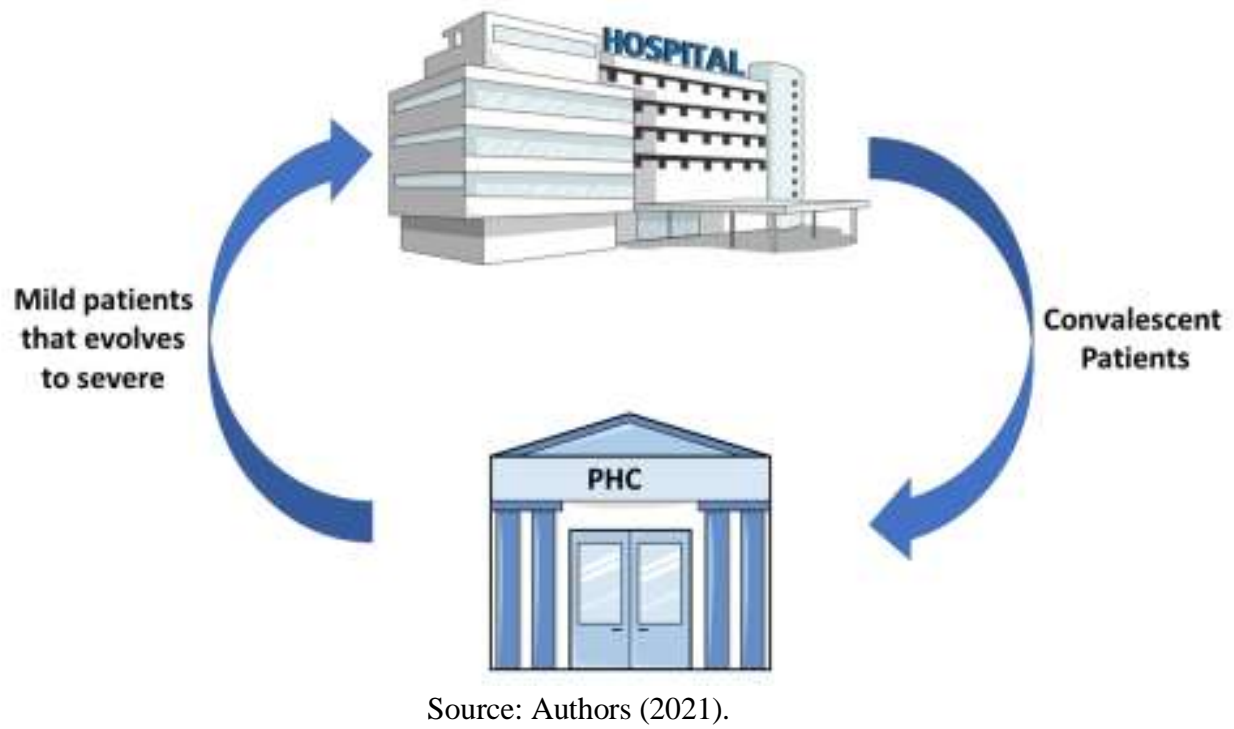

These patients, although cured, are convalescent with greater vulnerability, since they continue with their chronic diseases worsened by the COVID-19 infection. It is the PHC team that, besides the clinical management of mild cases, ensures continuity of care for recovered patients with local and home monitoring (WHO, 2020c). In the medium and long term, the 
repressed demand due to restriction in the maintenance of essential care of PHC and social isolation can result in increased demands of the health care system. This can generate a worsening of chronic diseases, the resurgence of other infections, such as tuberculosis and syphilis, and an increase in maternal and child mortality if the maintenance of primary care, such as prenatal care and child care, is interrupted (WHO, 2020c; Scott, Crawford-Browne, Sanders \&Webster, 2016).

Thus, PHC is essential in maintaining the health care of individuals and communities at the time of the pandemic. PHC plays a fundamental role in the protection and promotion of health, prevention and control of COVID-19 through early diagnosis, treatment and notification of mild cases, control and monitoring of chronic and convalescent conditions, and tracking and monitoring of infected people and their contacts (Harzheim et al., 2020).

\section{The Challenges of Primary Health Care in the COVID-19 Pandemic}

This pandemic scenario showed that health policies are essential and that a series of measures to contain the transmission of COVID-19 are necessary to prevent the collapse of health services. Emphasizing the need for hospital care, without excluding or neglecting PHC actions and thereby fragmenting health care assistance, is a challenge for managers of health system (Harzheim et al., 2020).

The displacement of the COVID-19 approach to scenarios other than the hospital produces the need to take knowledge to other levels of assistance in order to guarantee the availability and continuity of care. A challenge for PHC teams is to not disrupt the assistance provided to priority groups, guaranteeing essential services while still assisting suspected patients, who may evolve to severity, maintaining their stability until transfer, along with patients after hospital discharge, offering the care they need given their vulnerability (Figure 3). It shows the main actions PHC needs to take during the COVID-19 pandemic.

In this way, in the context of PHC, the pandemic is causing changes in the care process. Unlike the hospital whose architecture, structure and process favor a controlled environment, the PHC has precarious structures that are often precarious and different work processes. The setting of primary care and community assistance are, by implication, considered "low risk" (Greenhalgh et al., 2020). However, in this pandemic, with asymptomatic and vulnerable groups, the need to exercise care without promoting contagion, protecting professional, patients and the community is transforming this configuration.

Another change occurs in the access of primary care units. These units that used to have open doors, now require physical barriers to maintain distance, with control and limitation of entry, circulation and flow. This can generate an emptying of primary care units and interfere with the effectiveness of service, causing setbacks in the assistance provided.

The way healthcare occurs through bonding between health professionals and patients also have changed. The distance and the PPE establish limits and confuse the identity. Face-to-face contact is interrupted by the usage of masks and physical barriers that are imposed to maintain distance. The implementation of consultation methods by video, by messages on the cell phone or by phone between the PHC and the user is still a challenge (Webster, 2020).

The lack of testing and the absence of modeling of the disease make it difficult to establish health policies and resource optimization, keeping professionals anxious and under great tension. Modeling the COVID-19 pandemic is a challenge, but it is possible to use data that can be used to project resource demands. A conservative reproduction estimate shows that, at the beginning of the COVID-19 epidemic, each infected person, on average, spreads the virus to at least two other people, and approximately $80 \%$ of infected people are asymptomatic or have mild symptoms. Thus, these conditions represent a danger for the assistance team and for the community (Kvalsvig et al., 2020). 
Figure 3. Diagram of PHC challenges.

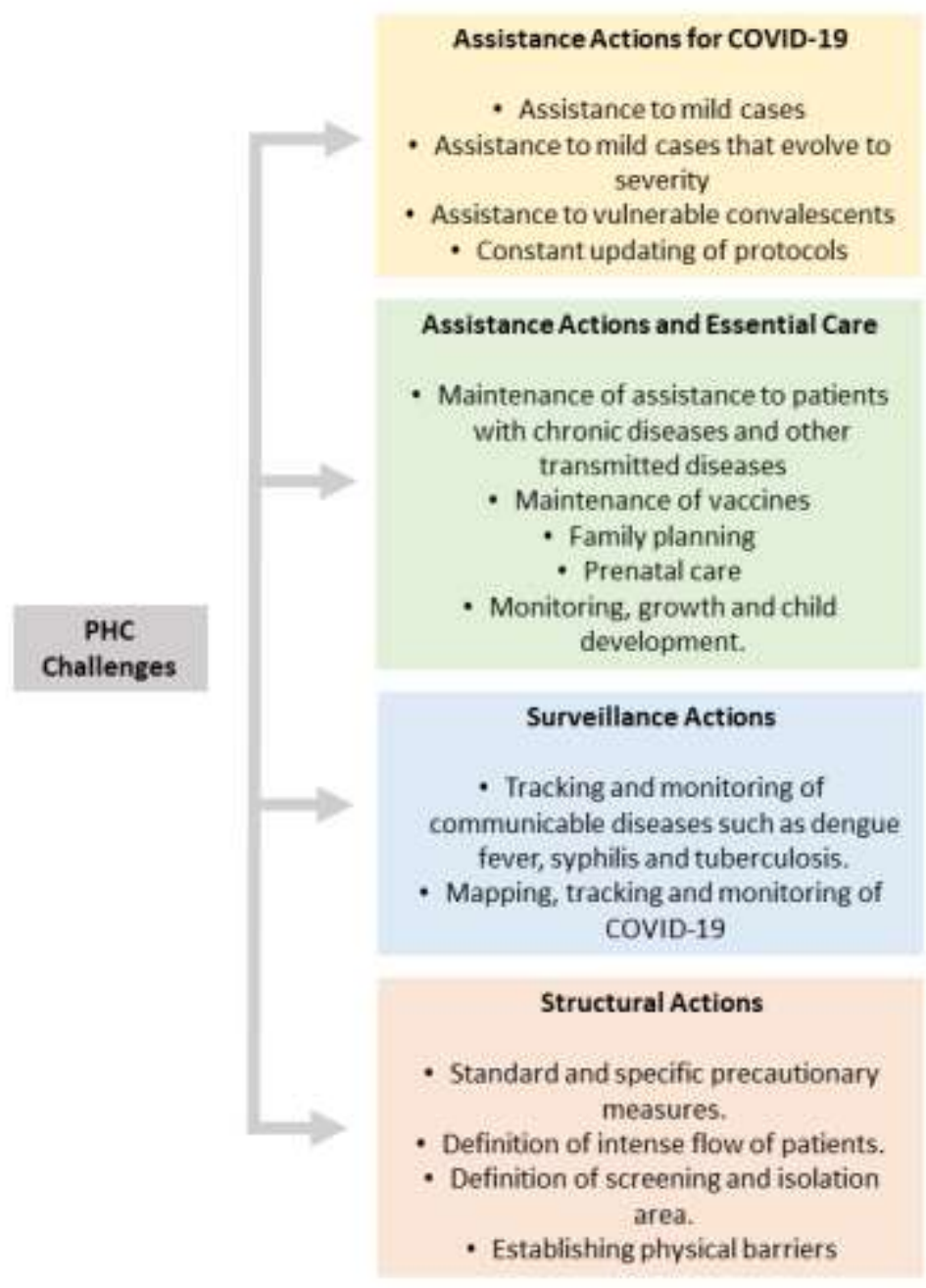

Source: Authors (2021).

It is necessary and urgent to prepare PHC teams for the clinical management of the disease and for the measures of precaution to ensure adequate care to all patients (6). Several studies indicate that PHC professionals do not have or have little specific knowledge about the precautions against the disease (Kvalsvig et al., 2020; WHO, 2020b).

Knowledge about these precautions is essential, but many other factors, such as the lack of structure and training, the guarantee of materials, conflicts of professional roles, and professional skills can affect these practices (Sako et al., 2018; Alfahan et al., 2016; Shukla, Tyagi \& Gupta, 2016). For this reason, this pandemic has shown the need for a quick and organized response between the different healthcare levels, besides implementation of a monitoring system and preparation for epidemics that is sensitive, capable and efficient (Fauci, Lane \& Redfield, 2020). Reacting with the necessary effectiveness implies having a technical capacity, sufficient number of professionals and inputs to care for individuals and for the guidance of the population on prevention and containment of the disease.

\section{Recommendation for PHC practices for the prevention, control and monitoring of COVID-19}

The main actions for an effective response seem to be extensive testing, contact tracking, an emphasis on diagnosis and home care, and monitoring and protection of essential care (26). Local actions may depend on three factors related to infection: (i) the number of people infected, (ii) the transmissibility of the infection, and (iii) the distribution of clinical severity 
among those infected (1). These actions aim to stop the disease outbreak, treat infected people, guarantee essential services, preserve the stability of the health system and prevent new outbreaks. In other words, these actions involve measures to intensify the prevention and control of infections in the healthcare unit and community. The recommendations for PHC include:

1. Reinforce COVID-19 prevention strategies for the community (Harzheim et al., 2020).

2. Maintain essential care and longitudinal community monitoring such as vaccination, maintenance of urgent and emergency dental health appointments, supply of medications and care for chronic patients or those with other needs (Harzheim et al., 2020, WHO, 2020b).

3. Provision of a telemedicine and telehealth platform for multiprofessional care or virtual medical appointment, focusing on people with chronic conditions, prenatal care and other conditions (Harzheim et al., 2020).

4. Identify elective procedures and treatments that can be postponed and extend the duration of medication prescriptions for chronic patients (Scott, Crawford-Browne \& Sanders, 2016).

5. Establish a list of vulnerable groups, evaluating and mitigating access barriers that they may experience. This group includes elderly people, people with mental disorders, migrants, refugees, people with physical or mental disabilities, people with low literacy who may not understand orientations, people who are geographically or socially isolated at home, and people who are chemically dependent (Gawande, 2020).

6. Promote the establishment of an information network through patients and their families, so that they can bring to the healthcare unit information about relatives, neighbors and other people in social life who are at risk such as of domestic violence, abandonment or depression.

7. Maintain home visits to vulnerable groups and people without access to the telephone or internet to evaluate the necessity for more advanced care, review the availability and proper use of medications and home control measures. This would contribute to the management of health conditions, even with isolation, allowing physical and mental monitoring of vulnerable patients (WHO, 2020b; Haines et al, 2020).

8. Increase home care, including early oxygen therapy and adequate nutrition for mildly ill and convalescent patients. This could limit the hospitalization to just patients with high severity illness, reducing contagion, protecting patients and healthcare professionals and minimizing the consumption of PPE (Nacoti et al., 2020; WHO, 2020b).

9. If available, remote medical care can be provided through telemedicine $(6,9,20,29)$. "In Brazil, Telemedicine system was created to track, diagnose, treat and monitor patients with Flu Syndrome and COVID-19 “(Harzheim et al., 2020).

10. If available, use of information and communication technologies (ICT) suck as chatbot on the government page, government mobile app, and WhatsApp for screening for the presence of clinical symptoms of COVID-19 with a robotic flow ((Harzheim et al., 2020).

11. Monitor information on transmission and severity estimates that may differ, depending on the stage of the pandemic, to guide the effective response actions of PHC team, optimize resources for the use of PPE, and establish service, surveillance and monitoring flows (WHO, 2020d).

12. Implement and train professionals in clinical management protocols, fast tracks and guidelines for the care of suspected cases in PHC as an integral and active part of the health system (Harzheim et al., 2020, WHO, 2020b).

13. Implement care support with teleconsulting on COVID-19 for doctors and nurses in primary health care (Harzheim et al., 2020).

14. Train health professionals to use PPE properly and other standard precautions. All health professionals must wear surgical masks in all interactions with the patient, perform proper hand hygiene and disinfect all surfaces between visits. The surgical mask, a symbolic image of protection against COVID-19, must be resistant to liquids and protect the nose and mouth 
by providing a barrier against droplets. It must be used with eye protection (goggles or face shield) and be discarded when it is wet. N95 or PFF2 masks known as 'filter masks' are used to prevent inhalation of small airborne particles in aerosol generation procedures. The N95 mask should be discarded every time, but due to shortages it is being reused. In addition, studies of the Center of Disease Control (CDC) indicate that these masks can be reused five times, within the same shift, without losing the effectiveness of the filter, if it is intact, providing adequate adjustment and sealing. For non-aerosol-generating procedures, there is no evidence that PFF2 masks with respirators are better than surgical masks when both are used together with other PPE (WHO, 2020b, Padoveze \& Figueiredo, 2014; Greenhalgh et al., 2020).

15. Prepare the units facilities and establish standard procedures for the screening and PPE removal areas. Perform isolation of suspected cases and assistance with separate teams. Social distancing should be practiced with the waiting room having chairs separated by two meters (WHO, 2020b, Gawande, 2020; WHO, 2020d ).

16. Establish the screening of patients in the external area, ensuring that suspected patients are directed to the isolation area. These patients should not wait in the waiting room, they should receive surgical masks and be kept away from other patients and health professionals (Gawande, 2020).

17. Establish rotation of teams to deal with suspected cases in order to reduce exposure of professionals to viral load and optimize the use of equipment (Gawande, 2020).

18. Evaluate the demand generated for inputs and equipment, analyze whether the flow was adequate and what worked or failed in the service, through the number of cases admitted to the healthcare unit.

19. Map suspected and confirmed cases in the healthcare unit's territory by monitoring the numbers, distribution and location of these cases, allowing the assessment of necessary interventions in the community.

20. Track and monitor suspected cases and their contacts. Quarantine only those who have had close contact with the infected person. Close contact means fifteen minutes at a distance less than two meter without the use of a surgical mask. Monitoring can be performed according to available technologies, such as by telephone, home visit or informants (WHO, 2020b; Greenhalgh et al., 2020; Gawande, 2020).

21. Establish a flow including transportation and communication mechanisms between clinics and emergency services to transfer serious cases and allow more time for preparation for those who will receive the patient. The communication must be guaranteed between PHC and those who will receive a patient (WHO, 2020b).

22. Establish a protocol for preparing the patient for transport to minimize the environmental exposure in the facilities and prevent the exposure of employees, patients and unprotected visitors (WHO, 2020b).

23. In cases of laboratory testing, PHC may provide the results of tests performed with the appropriate information and guidelines for protection and control of the disease.

\section{Conclusion}

The COVID-19 pandemic exposed people's vulnerability and its spread highlighted the importance of having health system that are integrated and prepared for pandemics, with good infrastructure, health professionals and quality of service. It sparked reflections on the right to health, on the guarantee of public health, on actions and standards of health services and their implications on the response capacity to the population.

The management of mild cases and of patients with chronic conditions by the PHC professionals can reduce the financial burden and hospitalizations due to complications of these diseases. The reduction of hospital admissions is crucial at the moment of insufficient hospital's beds and risk of collapse of capacity of the hospital.

Primary care is important to strengthen the prevention and control of COVID-19 and to emphasize the role of the community. It is necessary to increase the transfer of care within the community and within each individual's home to help 
reduce the impact of the disease on hospitals. The integration of all levels of care is essential since this pandemic can be seen as a public health and humanitarian health crisis.

This pandemic is not spread evenly across the world. Knowledge of the organization and occupation of space, territory and regional particularities enables to analyze the distribution of COVID-19 and the local needs and potential for prevention and control. PHC acquires an especial significance due to its territorial dimension, as it operates in communities and in homes, portraying the ways of life of different population groups, and outlining a socio-demographic, epidemiological and cultural profile. Therefore, the combat against this pandemic cannot occur without the important role of PHC. All the information PHC has about its territory, whether in urban or rural areas, is an essential resource for pandemic control, generating an additional set of approaches to the socio-political context and, also, to the actions at front door of the healthcare system.

Studies on PHC performance during the pandemic may increase the knowledge about its importance in planning and management activities, which may assist in organizing a more effective response and in defining the most appropriate resources and tools to be used in control of new outbreaks.

In view of the reflections presented, there is a need to establish new studies related to the impact and development of PHC actions, especially in the follow-up of people who developed the Post COVID-19 Syndrome and provision of vaccination. It is important to analisy the performance and challenges of PHC in the the planning, programming and organization of the vaccination offer, considering the specificity of each territory, in order to favor the population's access.

\section{References}

Alfahan, A., Alhabib, S., Abdulmajeed, I., Rahman, S., \& Bamuhair. S. (2016) In the era of corona virus: health care professionals' knowledge, attitudes, and practice of hand hygiene in Saudi primary care centers: a cross-sectional study. J Community Hosp Intern Med Perspect, 6(4), 32151. https://doi.org/10.3402/jchimp.v6.32151

Barbosa, S. P., \& Silva, A. V. F. G. (2020). A Prática da Atenção Primária à Saúde no Combate da COVID-19. APS em Revista, 2(1), 17-19. https://doi.org/10.14295/aps.v2i1.62

Brasil (2017). Ministério da Saúde. Portaria $n^{\circ} 2.436$, de 21 de setembro de 2017. Aprova a Política Nacional de Atenção Básica, estabelecendo a revisão de diretrizes para a organização da Atenção Básica, no âmbito do Sistema Único de Saúde (SUS). https://bvsms.saude.gov.br/bvs/saudelegis/gm/2017/prt2436_22_09_2017.html

Castro, M. C., Massuda, A., Almeida, G., Menezes-Filho, N. A., Andrade, M. V., \& Noronha, K. V. M. S. et al. (2019). Brazil's unified health system: the first 30 years and prospects for the future. Lancet, 394(10195), 345-56. https://doi.org/10.1016/S0140-6736(19)31243-7.

Cueto, M. (2020). The origins of primary health care and selective primary health care. Am J Public Health, 94(11), 1864-74. https://doi.org/10.2105/ajph.94.11.1864

Fauci, A. S., Lane, H. C., \& Redfield, R. R. (2020). Covid-19 - Navigating the Uncharted. $N$ Engl $J$ Med., 382(13), 1268-9. https://doi.org/10.1056/NEJMe2002387.

Freitas, A. R. R., Napimoga, M., \& Donalisio, M. R. (2020) Assessing the severity of COVID-19. Epidemiol. Serv. Saúde, 29(2), e2020119. https://doi.org/10.5123/S1679-49742020000200008.

Gawande, A., (2020). Keeping the Coronavirus from Infecting Health-Care Workers. The New Yorker. https://www.newyorker.com/news/news-desk/keepingthe-coronavirus-from-infecting-health-care-workers

Greenhalgh, T., Koh, G. C. H., \& Car, J. (2020). Covid-19: a remote assessment in primary care. BMJ, 368: m1182. https://doi.org/10.1136/bmj.m1182.

Greenhalgh, T., Chan, X. H., Khunti, K., Durand-Moreau, Q., Straube, S., \& Devane, D. et al. (2020). What is the efficacy of standard face masks compared to respirator masks in preventing COVID type respiratory illnesses in primary care staff? The Centre for Evidence-Based Medicine develops, promotes and disseminates better evidence for healthcare. https://www.cebm.net/covid-19/what-is-the-efficacy-of-standard-face-masks-compared-to-respirator-masks-inpreventing-covid-type-respiratory-illnesses-in-primary-care-staff/

Harzheim, E., Martins, C., Wollmann, L., Pedebos, L. A., Faller, L. A., \& Marques, M. C. et al. (2020). Federal actions to support and strengthen local efforts to combat COVID-19: Primary Health Care (PHC) in the driver's seat. Ciênc. saúde coletiva, 25(1), 2493-2497. https://doi.org/10.1590/141381232020256.1 .11492020

Kvalsvig, A., Barnard, L. T., Gray, L., Wilson, N., \& Baker, M. (2020). Supporting the COVID-19 pandemic response: Surveillance and Outbreak Analytics. https://www.health.govt.nz/publication/covid-19-modelling-and-other-commissioned-reports. 
Haines, A., Barros, E. F., Berlin, A., Heymann, D. L., \& Harris, M. J. (2020). National UK programme of community health workers for COVID-19 response. Lancet, 395(10231), 1173-5. https://doi.org/10.1016/S0140-6736(20)30735-2.

Lee, A., \& Morling, J. (2020). COVID19: The need for public health in a time of emergency. Public Health, 182, 188-9. https://doi.org/10.1016/j.puhe.2020.03.027.

Lipsitch, M., Swerdlow, D. L., \& Finelli, L. (2020). Defining the Epidemiology of Covid-19 - Studies Needed. N Engl J Med., $382(13), 1194-1196$. https://doi.org/doi.: 10.1056/NEJMp2002125.

Maroldi, M. A. C., Felix, A. M. S., Dias, A. A. L., Kawagoe, J. Y., Padoveze, M. C., \& Ferreira, A. S. et al. (2017). Adherence to precautions for preventing the transmission of microorganisms in primary health care: a qualitative study. BMC Nurs., 16: 49. https://doi.org/doi: 10.1186/s12912-017-0245-z.

Nacoti, M., Ciocca, A., Giupponi, A., Brambillasca, P., Lussana, F., \& Pisano, M. et al. (2020). At the Epicenter of the Covid-19 Pandemic and Humanitarian Crises in Italy: Changing Perspectives on Preparation and Mitigation. $N$ Engl J Med., https://catalyst.nejm.org/doi/full/10.1056/CAT.20.0080

Padoveze, M. C., \& Figueiredo, R. M. (2014) The role of primary care in the prevention and control of healthcare associated infections. Rev. esc. enferm., 48(6), 1137-1144. http://dx.doi.org/10.1590/S0080-623420140000700023.

Pereira, A, S.; Shitsuka, D. M.; Parreira, F. J.; Shitsuka, R. Metodologia da pesquisa científica. UFSM. https://repositorio.ufsm.br/bitstream/handle/1/15824/Lic_Computacao_Metodologia-Pesquisa-Cientifica.pdf?sequence=1

Starfield, B. (2002). Atenção primária: equilíbrio entre necessidades de saúde, serviços e tecnologia. Brasília: UNESCO, Ministério da Saúde, 2002.

Scott, V., Crawford-Browne, S., \& Sanders, D. (2016). Critiquing the response to the Ebola epidemic through a Primary Health Care Approach. BMC public health., 16: 410. https://doi.org/10.1186/s12889-016-3071-4.

Sako, M. P., Felix, A. M. S., Kawagoe, J. Y., Padoveze, M. C., Ferreira, A. S., \& Zem-Mascarenhas, S. H. et al. (2018). Knowledge about precautions in Primary Health Care: tool validation. Rev. Bras. Enferm., 71(Suppl 4), 1589-1595. https://doi.org/10.1590/0034-7167-2017-0886.

Shukla, M., Tyagi, S., \& Gupta, N. K. A (2016). Study on Knowledge of Hand Hygiene among Health Care Personnel in Selected Primary Health Care Centres in Lucknow. Int J Health Sci Res., 6(3), 22-26. https://www.ijhsr.org/IJHSR_Vol.6_Issue.3_March2016/4.pdf

Tan, K. B., \& Lee, C. E. (2020). Integration of Primary Care with Hospital Services for Sustainable Universal Health Coverage in Singapore. Health Syst Reform., 5(1), 18-23. https://pubmed.ncbi.nlm.nih.gov/30924743/

Webster, P. (2020). Virtual health care in the era of COVID-19. Lancet, 395(10231), 1180-1. https://doi.org/10.1016/S0140-6736(2)30818

World Health Organization. WHO (2018). Declaration of Astana. Global Conference on Primary Health Care: From Alma-Ata towards Universal Health Coverage and the Sustainable Development Goals. https://www.who.int/primary-health/conference-phc/declaration.

World Health Organization. WHO (2020a). Report of the WHO-China Joint Mission on Coronavirus Disease 2019 (COVID-19). https://www.who.int/docs/default-source/coronaviruse/who-china-joint-mission-on-covid-19-final-report.pdf.

World Health Organization. WHO (2020b). Strengthening the health system response to COVID-19. Recommendations for the WHO European Region. Policy brief (1 April 2020). http://www.euro.who.int/en/health-topics/health-emergencies/coronavirus-covid-19/novel-coronavirus-2019-ncov-technicalguidance/coronavirus-disease-covid-19-outbreak-technical-guidance-europe/strengthening-the-health-system-response-to-covid-19

World Health Organization. WHO (2020c). Operational considerations for case management of COVID-19 in health facility and community. https://www.who.int/publications/i/item/operational-considerations-for-case-management-of-covid-19-in-health-facility-and-community

World Health Organization. WHO (2020d). Clinical management of severe acute respiratory infection when COVID-19 is suspected. https://www.who.int/publications/i/item/clinical-management-of-covid-19 